\title{
Is there a best practice? A better understanding of local economic development in rural Ontario
}

\begin{abstract}
Andrew Redden, Ec.D. (F)
This paper will look at the best practices of municipal-level local economic development (LED) in rural Ontario by examining survey results and interviews of working LED practitioners in Ontario. The research provides formal advice for rural municipalities looking to invest in a local economic development strategy, a subject previously absent from the published literature. The author has identified four essential actions as a starting point to deliver local economic development services in rural Ontario. They are (1) understand communities' markets and assets; (2) invest in a fulltime economic development officer; (3) recognize efforts of existing community organizations; (4) partner with neighbouring municipalities and participate in regional consortiums.
\end{abstract}

Keywords: Best practices, strategy, rural local economic development, Ontario

\section{Introduction}

There is a general dearth of studies that examine the practice of local economic development in rural Ontario. While research and writings do exist proclaiming the best practices overall for Canadian local economic development organizations to follow (EDAC, 2007; Blais \& Redden, 2009), there is little in the way of formal and published advice for rural municipalities looking to invest in a local economic development strategy (Douglas, 2003 \& 2004; The Monieson Centre, 2008). Unfortunately this is what rural municipalities require since they tend to be the "principle roots" of economic development (Bryant \& Douglas, 1995: 159).

Given the lack of information available, and the unique challenges rural communities and their economies face (Premier's Task Force on Rural Economic Renewal, 2001; Agricultural Odyssey Group, 2002; TORC, 2002; Drabenstott, 2003; Douglas, 2003; Flora et. al, 2004; Cytron, 2007; Collins-Williams, 2008), the need for an analysis on how rural local economic development is practiced, and should be, would be deemed "key investments for many municipalities and local groups" (Douglas, 2002: 12). There is a clear opportunity to assist rural municipal governments so that they can 'make educated decisions' on best practices that would not have been exposed otherwise (The Monieson Centre, 2008).

In this paper, the understanding of rural municipal economic development practice in Ontario is furthered. This is accomplished through a review of the results of a survey of a nonprobabilistic purposive random sample of rural Ontario municipalities carried out through the summer months of 2009. Questions focused on how economic development is facilitated 
currently in rural municipalities as well as one that asked respondents to indicate a rural Ontario municipality, or rural municipalities, which in their view best exemplify a model of best practice in local economic development. The most popular were later contacted and interviewed to learn more about how they practice local economic development. Finally, cross-referencing the findings with that of a literature review (including the nominal amount of research and literature focusing on rural economic development practice in Ontario), helps generate a set of recommendations for rural Ontario municipalities, their economic development officers (where in place) and other municipally assigned consortiums to follow when investing in local economic development. Those recommendations are provided at the end of this paper.

\section{Defining 'rural' Ontario municipality}

For the purposes of this paper, a definition of what is a rural Ontario municipality was adopted from the Ontario Ministry of Agriculture, Food \& Rural Affairs (OMAFRA) Working Definition of Rural. It was obtained from their Rural Economic Development Data \& Intelligence (REDDI) Internet website ${ }^{1}$. OMAFRA considers rural Ontario to be that area of the province outside of the nine urban areas including the City of Hamilton, City of Ottawa, City of London, City of Windsor, The Greater Toronto Area, The Region of Niagara, The Region of Waterloo, The City of Thunder Bay, and the City of Greater Sudbury. Also, rural includes those municipalities with a population of less than 100,000. However, while OMAFRA does consider GTA municipalities with a population under 100,000 to be rural, for the purposes of this research, all of the communities within the Greater Toronto Area (GTA) as shown in Figure 1, regardless of population, are excluded in this paper's definition of a rural municipality.

Additionally, it is worth noting that northern Ontario was included in the rural definition. While acknowledging that northern Ontario municipalities may have unique issues compared to their southern Ontario counterparts, this author felt that they still fit the definition of rural.

Furthermore, to not include northern Ontario simply on the basis of differing rural issues would set a precedent to force separation of south-western Ontario municipalities and south-eastern Ontario municipalities from one another as they do have differing "glaring and continuing structural disparities" between themselves (Douglas, 2004: 31).

\section{Literature review}

This literature review is divided into two major sections. The first introduces and makes reference to some of the literature covering the unique challenges that rural communities face compared to urban areas with respect to their economies and economic development. The second section provides a review and analysis of the literature focusing on the practice of local economic development with specific attention given to the body of literature that looks at how

\footnotetext{
${ }^{1}$ http://www.reddi.gov.on.ca
} 
best to practice local and rural economic development. The limited amount of research covering local economic development in rural Ontario is also included.

Figure 1: Greater Toronto Area (GTA) map

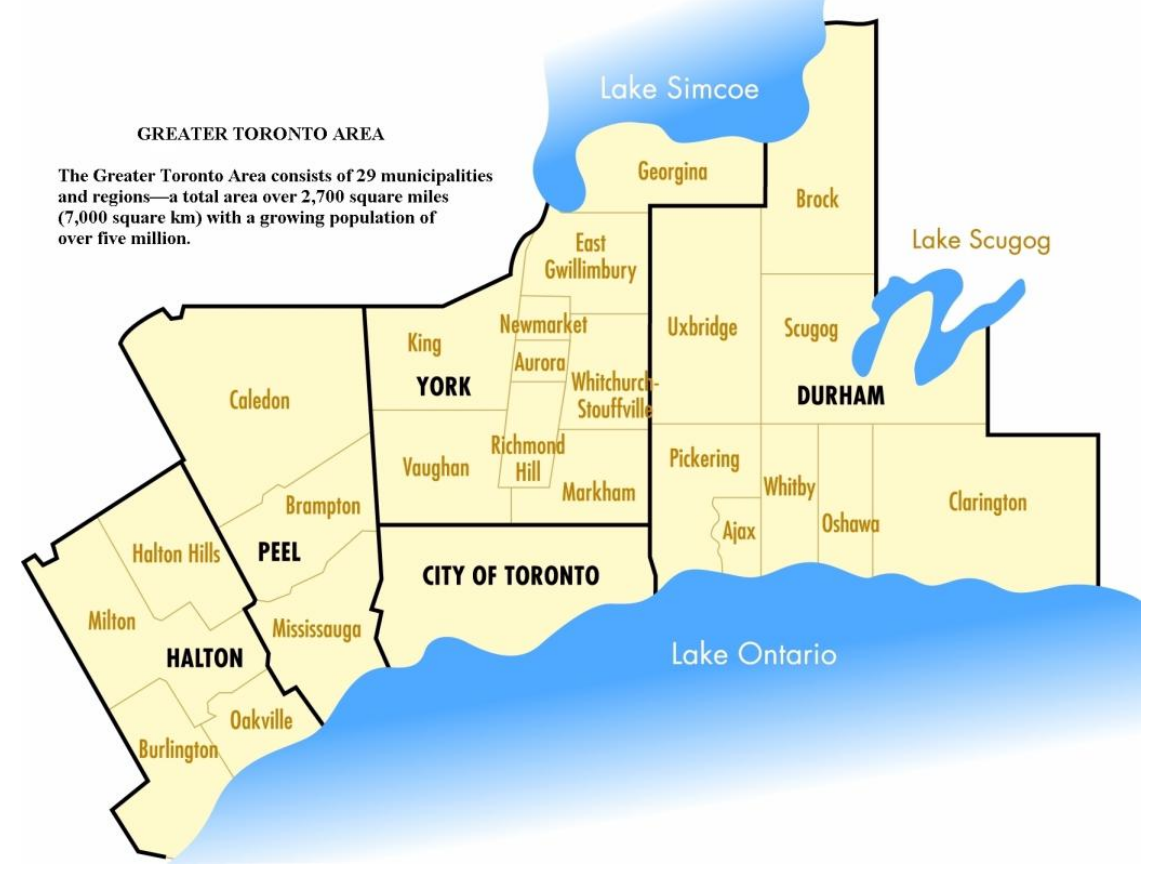

Source: Greater Toronto Marketing Alliance. (n.d). Map of Greater Toronto Area. Retrieved from www.greatertoronto.org.

\section{The challenges rural municipalities face}

Rural municipalities face some unique challenges compared to their urban cousins when it comes to the practice of economic development. The demographic and economic composition of rural Ontario is varied and experiencing profound change (Ontario Premier's Task Force on Rural Economic Renewal, 2001). As Howland (1993: 61) noted, "rural economies are small, undiversified, and disproportionately comprise a low-skilled labour force".

A perfect example of a difference is the aging of rural communities. As "baby boomers reach their $65^{\text {th }}$ birthdays, more people will be leaving the GTA (Greater Toronto Area) to retire in other parts of Ontario", and they yearn for the lifestyle that small towns and villages in rural communities supply (Levman, 2004: N8). This poses some interesting challenges on the traditional rural farm communities when "transplanted urbanites" come from cities "to live, play or just enjoy” (Agricultural Odyssey Group, 2002: 77). Likewise, an aging population puts strains on housing and service provision for the elderly. 
Further adding to the aging situation is the out-migration of rural young adults (Premier's Task Force on Rural Economic Renewal, 2001; Agricultural Odyssey Group, 2002; Drabenstott, 2003; Redden, 2005). Likewise, rural communities are facing challenges keeping their schools open due to declining enrollment (Perkins, 2009) and this may be attributed to a decline in the number of young adults choosing to start their families in a rural setting. A recent Canadian Government report estimated only one in four rural youth who leave their communities will return within ten years (Malatest \& Associates, 2002). As Highman and Rathge (1998: 22) stated, a shortage of young adults has "important ramifications" for a community to grow.

Overall, the economies of Ontario's rural regions are different from their urban counterparts in terms of size, dynamics and specializations. Some examples include:

- predominance / history of agribusiness and family farming;

- reliance on government funding to sustain business and projects (examples include the Eastern Ontario Development Fund (provincial) and Eastern Ontario Development Program (federal);

- smaller tax base;

- the access and distance to markets (customers) is poor compared to large urban areas (save the Internet); and

- a shortage of available serviced industrial and commercial lands to attract investment.

In contrast, urban centres are supported by a mixture of manufacturing, advanced services and government and trade (Howland, 2003). They also enjoy larger economic development departments often filled with several economic development officials and resources while rural communities typically have far less resources and cannot usually afford to hire specialized economic development staff (Premier's Task Force on Rural Economic Renewal, 2001). Furthermore, "Remoteness, lack of public infrastructure, and low population densities all make attracting private enterprise difficult" (Cytron, 2007: 3).

Further adding to the challenge of attracting private enterprise is the decline in the natural resources, agriculture and rural manufacturing industries. This also severely affects rural municipalities' employment base (Pezzini \& Wojan, 2001; Premier's Task Force on Rural Economic Renewal, 2001; Cytron, 2007; Collins-Willams, 2008). While the scale of farm operations is growing, the size of farms is getting smaller causing some rural farm families to give up their independence to remain viable and choose off-farm income (Agricultural Odyssey Group, 2002). The forestry sector is also "hurting" putting many people out of work and creating hardships from the "disappearance of the best-paid work on a small community" (CBC News, 2009). Further adding to the pain is the trend of manufacturing plant closures in some of the larger rural communities situated along the Provincial 401 highway that have provided 
employment to, but recently laid off, numerous residents in the outlying rural areas (Tremblay, 2008).

A lack of access to broadband is also a barrier to business in rural areas. According to the Canadian Radio-television and Telecommunications Commission (CRTC, 2009), while all urban households can have access to broadband, $22 \%$ of rural Canadian households do not. Broadband is considered essential for participating in today's economy "as it enables citizens, businesses and institutions to access information, services and opportunities that could otherwise be out of reach" (Industry Canada, 2009).

\section{Local economic development in rural Ontario municipalities}

Aside from the distinct economic and accompanying social challenges described above, a major challenge for rural Ontario's municipalities is understanding the best approach to take since "researchers are generally located in urban centres and as such, are more attuned to and inspired by urban issues" (The Monieson Centre, 2008). Perhaps that is why a study of local economic development in rural Ontario found that less than one third of rural municipalities "felt that local economic development capacity was in place, either in the municipality itself or in their local community" (Douglas, 2004: 31).

The practice of local economic development in rural Ontario "is generally characterized by very small investments of staff time" (Douglas, 2003:XXV). For example, Bryant and Douglas (1995) found that large Ontario cities like Toronto, London and Windsor enjoy higher budgets and more full-time staff to cover economic development in contrast to rural Ontario municipalities. Specialization of roles is also viewed to be prevalent in larger versus smaller municipalities. Bryant and Douglas (1995) also observed larger urban communities assigning a team of economic development staff to each focus on specialized areas or projects such as business retention and expansion, the movie industry, downtown revitalization or investment marketing, while smaller rural municipalities had just one staff person, if any, to take on all areas in a clearinghouse role.

Another observation is that some rural economic development offices have adopted the view that the traditional effort of trying to attract large industry is outmoded (Stirling-Rawdon, 2005: 24, Prince Edward County, 2004: 55). Take for example Cytron (2007: 3) who noted that in recent years rural economic development practitioners have been "bolstering economic opportunities and quality of life in rural areas through approaches that seek to build upon the unique strengths and capacities of rural places". Some rural municipalities like Prince Edward County have chosen to focus their efforts on targeting smaller sized business and entrepreneurs seeking quality of life in quality of place, while their neighbour Hastings County to the north draws upon 
the emerging interest of local farmers in hops and malted barley to bring one or more micro breweries to the area (Richards, 2009).

Although a few rural communities like Prince Edward and Hastings Counties have completed strategies focusing on the smaller entrepreneur, others may struggle just getting to the point of knowing what approach to take. That is why Douglas (2004: 31) completed the "first ever comprehensive assessment of local economic development practice in rural Ontario". His 2003 report titled "Toward More Effective Rural Economic Development in Ontario" contains the results of a three-year research project. While his report highlights "that there is not any one model of 'best practice' that Ontario's rural municipalities see as a paragon of best practice" (Douglas, 2003: 15), he provided a set of twelve recommendations for rural municipalities in Ontario which is summarized as follows (2003: 2):

1. Invest in the position of a designated individual such as an Economic Development Officer (EDO).

2. If it is not feasible to hire an EDO, institute a "Rural Economic Development Consortium" (REDC).

3. Re-establish close working relationships with Community Futures Development Corporations (CFDCs).

4. Train and re-train Municipal Council, their Committees and other partners in local economic development.

5. Expand community participation in local economic development through a number of means such as involving rural youth, engagement of residents and local groups in surveys and intensify communications on what is being practiced.

6. Integrate tourism development initiatives with all other economic development activities.

7. Recognize that economic development practice is changing to matters of partnership building, community communications, media management, public participation, facilitation and other related aspects.

8. Be open to the changing rural economy versus the conventional approaches to local economic development.

9. Rural area municipalities must work with upper-tier municipalities and with the Province to design and formalize economic development services.

10. Recognize that what gets done in local economic development in rural communities is often a result of the commitment, energies and skills of resident volunteers.

11. Invest in an economic development strategy for the community whether at the local level or through the upper-tier, CFDC or a new REDC.

12. Recognize the distinction between different modes of practice in local economic development (i.e. external investment recruitment, local business expansion, local investment facilitation) and use the local strategic planning process to chose among, or combine some or all of these. 
Although Douglas' top recommendation is to invest in the position of an EDO, others have emphasized rural communities focusing on their leadership, capacity and vision to effectively practice economic development to grow and stimulate their local economy (Premier's Task Force on Rural Economic Renewal, 2001), and some call attention to an integrated or regional partnership effort before any mention of hiring an EDO (Banovets et al. 2000; Drabenstott, 2003; The Monieson Centre, 2008).

A unique approach is the claim by Sirolli that "economic development is only one of the many developments a passionate culture brings forth" (1999: 117). He advocates that rural communities each hire an "Enterprise Facilitator" to fill the vacant storefronts on main street, put industry in the industrial parks and assist the struggling or new entrepreneur by providing confidential, free and competent consultation service (Sirolli, 2009). Sirolli used the analogy that Enterprise Facilitators are "trained like large animal veterinarians" in that they go directly to the entrepreneur, sit at their kitchen table and listen (Ibid). The Facilitator is designated to provide this free service when otherwise a municipal economic development officer (EDO) may not have the excessive time necessary to dedicate to every entrepreneur. He claimed that an EDO is too busy marketing the community, implementing programs and services such as broadband, practicing the beautification of main streets, compiling stats, data and so on.

In terms of the literature review, aside from published studies, there is also the Province of Ontario's Rural Economic Development \& Data Intelligence (REDDI) website ${ }^{2}$ that provides help to carry out research and strategies. However, this website mainly contributes to the information of rural Ontario's economies and helps support the research of an existing municipally assigned EDO or local agency rather than advise on how best to structure a local economic development function and role in the first place.

Despite a shortage of published supports for rural municipalities, there are some themes that are addressed in other Canadian publications that focus on municipal economic development in general.

For example, the Municipal World article by Blais and Redden (2009) identified key indicators any municipality should assess, regardless of size, or whether urban or rural. They discussed the importance of first completing a thorough understanding of what the municipality wants to accomplish through a strategic planning process. This may be followed by the establishment of either an internal department that reports through the administration to a municipal council (often with a volunteer advisory body consisting of public and private sector representatives), or an external body that reports to a board of directors composed of members of council, but also members of the private sector. Regarding which model is the one most widely practiced, 
research completed by consultants Millier Dickinson Blais in 2008 on upper-tier municipalities with 50,000 plus people, (Ibid: 20) indicated no clear majority use one or the other.

Blais and Redden (2009) also emphasized the importance of respecting the local capacity. For example, a municipality may already have a Chamber of Commerce, a Community Futures Development Corporation (CFDC) or a Business Improvement Area Association (BIA). "The municipality must work to develop a form that is strategic and flexible, filling gaps and taking responsibility for core services that are not being provided effectively or at all" (Ibid: 20). Further, they noted that municipalities must not forget performance measurement to track results and ensure the community and elected officials understand the progress being made which "unfortunately is not a common practice" (Ibid).

EDAC's (2007) Comprehensive Guide to Economic Development also does not distinguish between rural and urban, but acknowledges that there is no one right way to organize a local economic development program. One community's model of practice may not work elsewhere. However, the Guide does postulate some key principles that should be considered (2007: 12):

- Include all local groups involved in the economic development process.

- Encompass all economic development efforts in the community.

- The governing body of the economic development organization must include members of the power structure - the decisions makers - of the community.

- The governing body must have a high degree of autonomy, i.e. be able to take independent action without specific approval of a participating group such as the chamber of commerce or city government.

- While continuity of membership is important, make sure to infuse new people into the program.

- The governing body must meet regularly and frequently, preferably once a week.

- The organization must be adequately funded.

\section{Summary}

The preceding has provided an overview of some of the literature focusing on the challenges rural municipalities face with respect to their economies, as well as the literature focusing on the practice of local economic development by rural municipalities with attention paid to the recommended steps for initial action.

The next section explains the methodology used for this paper to research current practices of economic development in rural Ontario municipalities.

\section{Methodology}


The first step was to gather information on local economic development in rural communities. This was accomplished by conducting the review of the available literature. The purpose of researching the literature before conducting the survey of municipalities was to better understand what has already been studied and to develop appropriate questions to ask.

The next step involved developing a survey instrument. This was accomplished by developing an online survey and inviting rural municipalities to complete it. A copy of the invitation is included in Appendix A and a copy of the survey questions in Appendix B. The last question in the survey asked respondents to name at least one community that they felt was an exemplary model of best practice in rural local economic development.

This led to the final step of taking the three most commonly identified communities and contacting their economic development office to conduct a personal interview to learn more about how they practice local economic development.

It is important to note that the data from the surveys are not considered statistically representative. As Robson (1993) claimed, a case study is not a survey relying on the characteristics of research methods, sampling techniques and the sample size. However, with 100 surveys completed, a large non-probabilistic purposive sample was obtained from the total population of 407 rural municipalities.

\section{Research results}

This section introduces the findings from the primary data which was compiled through an online survey and personal interviews with rural municipalities across Ontario in the period June 3, 2009 to September 2, 2009. The results from the online survey are presented first. Then the more detailed data collected from personal interviews with three municipal economic development offices (Prince Edward County, the Township of Stirling-Rawdon and the City of Stratford) is provided.

\section{Results from the online survey}

An online survey was completed by 100 municipal respondents, from among the 407 municipalities fitting the rural definition and invited to participate, representing a $24.5 \%$ response rate. Surveys were completed during the period June 3, 2009 to July 31, 2009.

Municipalities were contacted by email following development of an email database sourced directly from the Ontario Municipal Directory published by the Association of Municipal Managers, Clerks and Treasurers of Ontario (AMCTO). A copy of the emailed letter of invitation 
can be found in Appendix A and a copy of the questionnaire in Appendix B. The pages that follow outline the findings from the questionnaire.

Respondents were first asked to indicate whether the municipality they are employed by is a single-tier, lower-tier or upper-tier in accordance with the Ontario Municipal Act, 2001.

As displayed in Figure 2, amongst the 100 respondents, 34\% represented single-tier municipalities, $56 \%$ lower-tier and $10 \%$ upper-tier counties or regions.

Respondents were asked to indicate the resident population of their municipality. Among the responses received, the average population was 15,287 residents. When applying a cross tabulation, the average resident population of single-tier municipalities was 9,785 . For lower tier municipalities the average size was 9,452 while upper tier respondents had an average population of 66,666 .

Respondents were asked if their municipality has an annual operating budget for economic development. $72 \%$ indicated that they have an economic development budget while $28 \%$ indicated that they do not.

\section{Figure 1: Survey results of municipality according to tier}

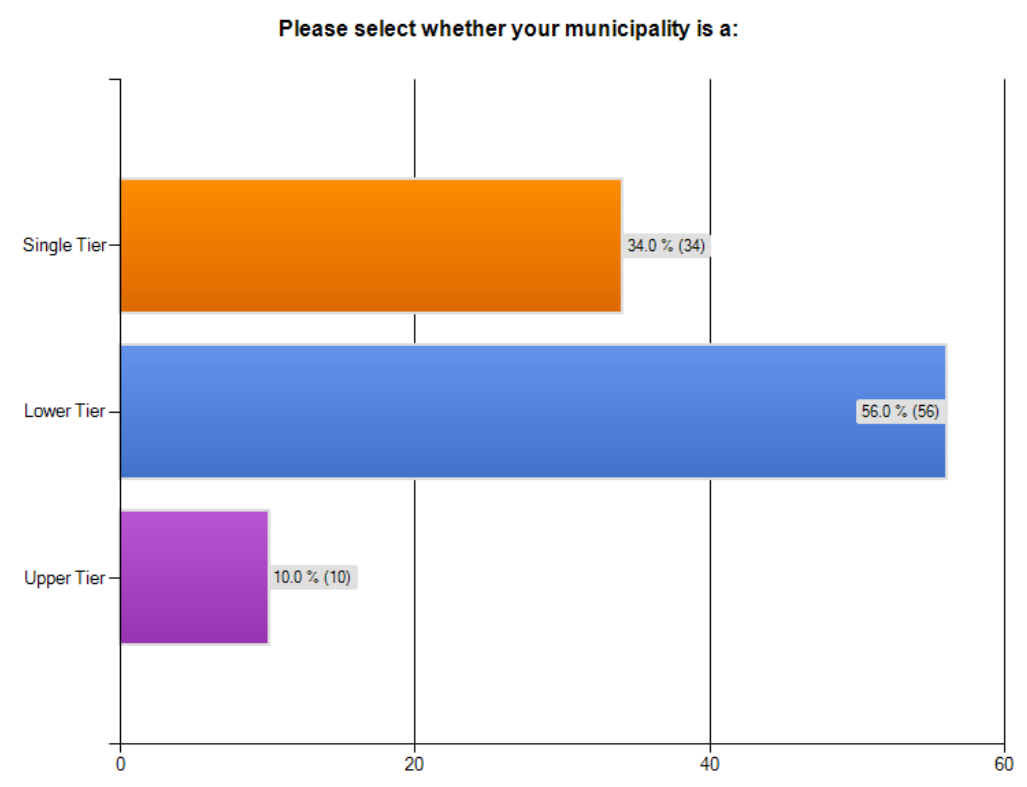

Respondents who indicated "Yes" were also asked to indicate the dollar amount of their budget for 2009 and outline (if possible) the percentage that covers salaries and/or project funding. The average total budget is $\$ 202,534$. The average amount that is dedicated to staff salaries is $\$ 72,108$ and the average amount dedicated to economic development projects such as investment marketing, business retention and expansion and other related initiatives is $\$ 130,426$. 
As shown in Figure 3, just 38\% of respondents indicated that their municipality has at least one full-time economic development professional on staff. When applying a cross tabulation to show the difference between lower-tier, single-tier and upper-tier municipal respondents, just $25 \%$ of lower-tier municipalities responded that they have at least one-full time economic development professional. In contrast, $70 \%$ of upper-tiers indicated they have at least one professional and amongst single-tiers the responses were split 50/50.

\section{Figure 2: Does your municipality have at least one full-time economic development professional on staff}

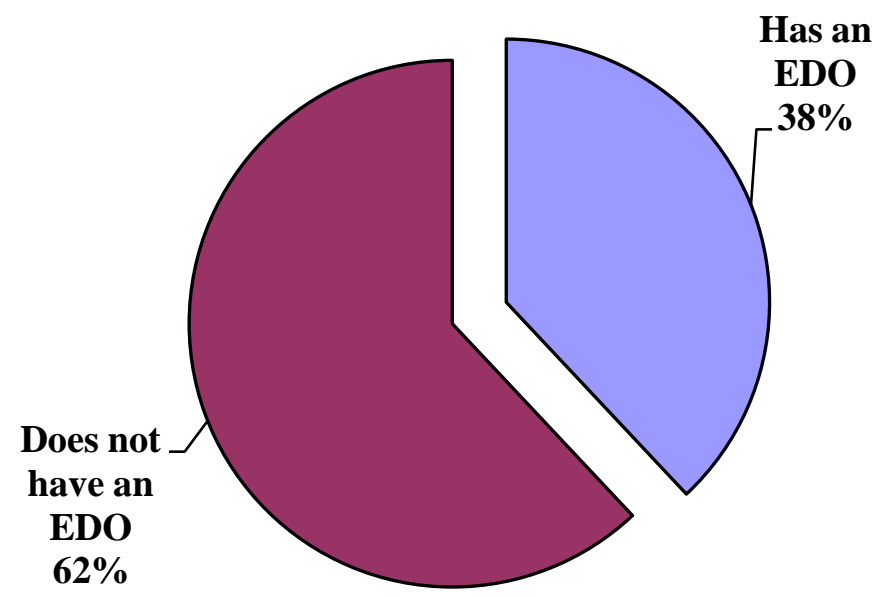

Those respondents who indicated that they do not have a full-time economic development professional on staff were asked to describe how economic development at the local level is managed in their community. There were numerous explanations provided, and therefore similar responses have been grouped together and the frequency of each is noted in Table 1. Most indicated that they utilize an appointed Municipal Economic Development Committee consisting of elected officials and members of the public, while others noted that their Council and senior staff take an active role and the remaining responses were varied amongst saying their Chief Administrative Officer (CAO), the upper-tier municipality or the municipal planner(s) take on the economic development role.

Respondents were asked to indicate the number of full-time and part-time staff as well as how many staff have their professional economic developer certification (Ec.D.) and Fellowship designation through the Economic Developers Association of Canada (EDAC). From a review of the responses in Table 2, not many respondents indicated that they have more than one fulltime economic development professional on staff. With regards to part-time staff, many municipalities have more than one part-time person providing these services and ten respondents indicated that they have one part-time person. Regarding professional certification, eleven 
respondents indicated that they have at least one staff member with their Ec.D. One respondent actually indicated they have four staff who have each obtained their Ec.D.

Table 1: How economic development at a local level is managed in the absence of a fulltime economic professional on staff at the municipal level

\begin{tabular}{|l|l|}
\hline Responsible individual or organization & Frequency of responses \\
\hline An Economic Development Committee & 15 \\
\hline Municipal Council and Senior Staff & 10 \\
\hline Chief Administrative Officer (CAO) & 9 \\
\hline $\begin{array}{l}\text { Upper-tier (in the case of lower-tiers not having a } \\
\text { full-time economic development professional on } \\
\text { staff) }\end{array}$ & 9 \\
\hline Municipal Planner / Director of Planning & 9 \\
\hline Part-time person and/or consultant & 7 \\
\hline $\begin{array}{l}\text { Community Futures Development Corporation } \\
\text { (CFDC) }\end{array}$ & 2 \\
\hline Community Development Officer & 2 \\
\hline Not actively addressed & 3 \\
\hline
\end{tabular}

Municipalities were asked to describe the reporting relationship of municipal economic development staff. For example, this question was intended to learn whether they report to a municipal clerk, the Chief Administrative Officer or a Department Head. Amongst the 63 respondents who answered this question, $48 \%$ indicated a direct reporting relationship to a CAO, $14 \%$ indicated a reporting relationship with the municipal Clerk-Administrator and the same percentage to a Board of Directors (which, based on responses, includes a committee of council, a Community Futures Development Corporation or the board of a separate agency contracted for economic development services). Just 13\% indicated that they report to a Director or Commissioner of Planning \& Development while just one respondent indicated a reporting relationship with a Director of Community Services.

Respondents were asked to describe their municipality's core-proactive responsibilities in delivering economic development services to their local community. Table 3 shows the various open-ended responses received. Since there were numerous explanations provided, similar responses have been grouped together and the frequency of each is noted. As observed in Table 3, the top five responsibilities include Business Retention \& Expansion, Tourism Marketing, Investment Attraction, Downtown Revitalization and Community Development. 
Table 2: The total number of full-time staff and the total number of part-time staff employed to work on economic development

\begin{tabular}{|c|c|c|c|c|c|c|c|c|c|c|c|c|}
\hline \multirow[b]{2}{*}{$\begin{array}{l}\text { Answer } \\
\text { Options }\end{array}$} & \multicolumn{11}{|c|}{ Number of staff } & \multirow[b]{2}{*}{$\begin{array}{l}\text { Response } \\
\text { Count }\end{array}$} \\
\hline & None & 1 & 2 & 3 & 4 & 5 & 6 & 7 & 8 & 9 & $\begin{array}{l}10 \text { or } \\
\text { more }\end{array}$ & \\
\hline Full-time & 14 & 24 & 8 & 5 & 2 & 0 & 1 & 0 & 1 & 0 & 3 & 58 \\
\hline Part-time & 17 & 10 & 7 & 2 & 2 & 1 & 0 & 0 & 0 & 0 & 1 & 40 \\
\hline $\begin{array}{l}\text { Have obtained } \\
\text { Ec.D. }\end{array}$ & 36 & 11 & 1 & 0 & 1 & 0 & 0 & 0 & 0 & 0 & 0 & 49 \\
\hline $\begin{array}{l}\text { Have obtained } \\
\text { Ec.D.(F) }\end{array}$ & 34 & 3 & 0 & 0 & 0 & 0 & 0 & 0 & 0 & 0 & 0 & 37 \\
\hline
\end{tabular}

Respondents were asked if their municipality has any formal arrangement or partnerships with other municipalities or organizations to cooperate in delivering economic development services, projects, events or tourism. A majority of respondents (73\%) indicated that they do have a formal arrangement.

Respondents who said "Yes" were asked to describe their arrangement. Since there were numerous explanations provided, similar responses have been grouped together and the frequency of each is noted in Table 4. Several respondents indicated that their upper-tier municipality takes care of economic development on their behalf and often times tourism marketing. Others rely on regional organizations such as the Ontario East Economic Development Commission (OEEDC) or the Southwestern Ontario Marketing Alliance (SOMA) to help with investment attraction while tourism marketing is often administered by a local tourism or destination marketing organization.

The last question asked respondents to list a rural community, or rural communities, that they believe provides an example of "best practice" in rural economic development, and to explain why. A total of 54 separate communities were mentioned by respondents while 30 respondents said that they were "not sure". Although the survey was anonymous, some just named themselves and made it clear as such, while others appeared to list a neighbour. Overall, the responses reinforce suspicions that there is little knowledge of what would be considered a bestpractice among rural Ontario municipalities. As well, beyond respect or admiration for neighbouring municipalities' practices, or what they themselves are doing, it appears many of the respondents are not sure or convinced of any exemplary practice.

Table 3: Core-proactive responsibilities of rural Ontario municipalities in delivering economic development

\begin{tabular}{|l|l|}
\hline Core-proactive responsibilities & Frequency of responses \\
\hline Business Retention \& Expansion (BR+E) & 33 \\
\hline
\end{tabular}




\begin{tabular}{|l|l|}
\hline Tourism Marketing & 32 \\
\hline Investment Attraction & 31 \\
\hline Downtown Revitalization & 27 \\
\hline $\begin{array}{l}\text { Community Development (e.g. trails, } \\
\text { services, attractions) }\end{array}$ & 11 \\
\hline $\begin{array}{l}\text { Economic Development in general } \\
\text { (respondents who did not specify one or } \\
\text { more responsibility) }\end{array}$ & 10 \\
\hline Communications & 9 \\
\hline Physician Recruitment & 9 \\
\hline $\begin{array}{l}\text { Regional partnerships take on some } \\
\text { leading roles }\end{array}$ & 7 \\
\hline Special events & 6 \\
\hline Forestry / Natural Resources & 5 \\
\hline Agriculture \& Agri-ventures & 5 \\
\hline Expand Broadband access & 4 \\
\hline Small business support & 4 \\
\hline $\begin{array}{l}\text { Act as a resource to various other groups } \\
\text { such as Chamber of Commerce, BIA }\end{array}$ & 4 \\
\hline Youth retention / Skills development & 2 \\
\hline Creative services & 1 \\
\hline Accessibility planning & 1 \\
\hline $\begin{array}{l}\text { Upper-tier looks after economic } \\
\text { development }\end{array}$ & 1 \\
\hline Municipal land sales & 1 \\
\hline
\end{tabular}

Table 4: Partnering organizations that help deliver economic development services

\begin{tabular}{|l|l|}
\hline Partnering Organizations & Frequency of Responses \\
\hline $\begin{array}{l}\text { The upper-tier municipality (responsible } \\
\text { for economic development and } \\
\text { sometimes tourism services) }\end{array}$ & 30 \\
\hline $\begin{array}{l}\text { A regional formal body with a board of } \\
\text { directors (e.g. Southwestern Ontario } \\
\text { Marketing Alliance, Ontario East } \\
\text { Economic Development Commission) }\end{array}$ & 22 \\
\hline $\begin{array}{l}\text { A local tourism - destination marketing - } \\
\text { organization }\end{array}$ & 18 \\
\hline $\begin{array}{l}\text { Chamber of Commerce (often to conduct } \\
\text { tourism marketing) }\end{array}$ & 10 \\
\hline
\end{tabular}




\begin{tabular}{|l|l|}
\hline $\begin{array}{l}\text { Community Futures Development } \\
\text { Corporation }\end{array}$ & \\
\hline $\begin{array}{l}\text { A consortium (e.g. Greater Peterborough } \\
\text { Economic Development Commission) }\end{array}$ & 4 \\
\hline $\begin{array}{l}\text { Business Improvement Area Association } \\
\text { (BIA) }\end{array}$ & 4 \\
\hline $\begin{array}{l}\text { The Province - some mentioned working } \\
\text { closely with OMAFRA, MEDT, Ministry } \\
\text { of Tourism }\end{array}$ & 3 \\
\hline Small Business Enterprise Centre & 2 \\
\hline $\begin{array}{l}\text { Allocate funding directly to the Tourism } \\
\text { Information Centre }\end{array}$ & 1 \\
\hline
\end{tabular}

Nevertheless, the top three municipalities receiving the most frequent mentions are Prince Edward County (eight mentions), the Township of Stirlng-Rawdon (four mentions) and the City of Stratford (three mentions). Regarding Prince Edward County, brief reference was made to their arts and culture marketing, their focus on developing strategies around their local assets such as the wine industry and creating solid marketing and branding around their arts, culture and local agriculture assets.

Stirling-Rawdon's downtown revitalization efforts received attention along with their festival theatre as a strong draw. Their municipal support for economic development was cited as an exemplary model. For the City of Stratford, not a great deal of explanation was provided by respondents other than brief mention of their strong programs and partnerships.

To help obtain a better sense of why these three municipalities were cited, and make clearer recommendations on best practice, the three were personally contacted and an interview was conducted with a full-time economic development staff member including a review of their websites or published strategies. The results of those interviews are featured in Table 5.

\section{Summary of personal interviews}

The three rural municipalities that were interviewed are all actively engaged in local economic development and have taken a proactive approach. Table 5 provides an overview of their responses to a series of questions to learn more about how they practice local economic development.

\section{Discussion and recommendations}

As Douglas (2003: 15) proclaimed, “there is not any one model or 'best practice' that Ontario's rural municipalities see as a paragon of practice". While the results of this paper are consistent 
with that conclusion, this research does help to further the understanding of how rural Ontario municipalities are currently approaching local economic development efforts and provides some new guidance and recommendations.

Overall, from the three interviews summarized in Table 5, the results of the survey and the literature review, advanced practice is summarized as recognizing the following four actions:

1. Acquiring a good understanding of the local community's market and assets and then developing an economic development strategy that clearly reflects the local assets and advantages.

2. Investing in a full-time economic development officer (EDO), or equivalent (such as utilizing and supporting the upper-tier EDO), with appropriate experience and professional qualifications in local economic development.

3. Respecting local capacity by recognizing existing organizations in the community that already have a role in local economic development.

4. Partnering with neighbouring municipalities and participating in regional consortiums to help conduct investment marketing and other special projects that would not otherwise occur due to limited time, money and/or resources.

Acquire a good understanding of the local community's market and assets: Before a community can say that it is "open for business" and heads out to market itself, it needs to first do its homework. Advisably even prior to investing money towards hiring an EDO, it is important to start with an analysis of the local economy to help council and community partners understand what the current strengths and weaknesses are of the local economy. "Form follows function" meaning the economic development strategy is one of the first and foremost steps (Blais \& Redden, 2009). If one fails to pursue this process, economic development can be misdirected.

Considering the latest trend for rural municipalities to look beyond the traditional "smoke stack chasing", and instead working to attract the smaller entrepreneur such as in Prince Edward County, local assets should be properly understood and reflected in any promotional efforts distributed locally and to foreign investors.

Invest in a full-time economic development officer (EDO), or equivalent: This research paper adds to the body of literature endorsing the hiring of an economic development professional to commence (or continue) the research of the local market and assets, implement the economic development strategic plan, build local capacity and track performance. The survey uncovered the finding that just $38 \%$ of rural municipalities have a full-time EDO. Nonetheless, where a lower-tier municipality may decide not to invest in having their own staff for practical or financial reasons, they are advised to work with the existing EDO, or help hire an EDO, at the 
upper-tier county or regional government level to facilitate economic development on their behalf.

Working to fill the gaps in areas not already taken care of already must be completed when both a lower-tier and upper-tier practice economic development. In the case of Stirling-Rawdon, they provide a good example of a lower-tier benefiting from the services of their upper-tier, Hastings County. While Stirling-Rawdon and their EDO focus more on locally based marketing and tourism, infrastructure and planning such as their Community Improvement Plan and main street revitalization projects, the County's Economic Development Strategy (2007) emphasized filing the gaps for services not fulfilled already (e.g. investment attraction, business retention \& expansion) while acting as a centralized source of market research while partnering and promoting local initiatives. Also, by having an EDO at the County level, the other thirteen municipalities in the County, especially the ten that do not have their own EDO, benefit from some investment attraction and assistance with local economic development planning and management.

In communities that do not have an EDO at either their local or upper-tier level, they are advised to utilize the services of their local Community Futures Development Corporation (CFDC). As is evident in the findings of the survey, when a full-time EDO is absent, not many indicate utilizing their CFDC. 
Table 5: Results from the personal interviews

\begin{tabular}{|c|c|c|c|}
\hline & Prince Edward County & Township of Stirling-Rawdon & City of Stratford \\
\hline Is there an EDO? & $\begin{array}{l}\text { Yes - } 2 \text { FT and on average } 1 \text { to } 4 \\
\text { additional on contract (dependent } \\
\text { on funding); other partners in } \\
\text { County working in concert and } \\
\text { have staff }\end{array}$ & Yes - $1 \mathrm{FT}$ & $\begin{array}{l}\text { Yes - } 2 \text { FT \& } 1 \text { Admin. } \\
\text { Assistant }\end{array}$ \\
\hline $\begin{array}{l}\text { Annual Operating } \\
\text { Budget }\end{array}$ & $\begin{array}{l}\text { \$1.1 million including grants } \\
(\$ 390,000 \text { local contribution) }\end{array}$ & $\$ 90,000$ & $\begin{array}{l}\$ 586,000 \text { ( } \$ 155,000 \text { to Small } \\
\text { Business Enterprise Centre) }\end{array}$ \\
\hline $\begin{array}{l}\text { Budgetary trend } \\
\text { over the last } \\
\text { several years }\end{array}$ & Increasing due to grants & Stable & Stable \\
\hline $\begin{array}{l}\text { Reporting } \\
\text { relationship }\end{array}$ & $\begin{array}{l}\text { Commissioner of Corporate } \\
\text { Services \& Finance; No } \\
\text { Economic Development } \\
\text { Committee but report to } \\
\text { Committee of the Whole }\end{array}$ & $\begin{array}{l}\text { Clerk-Administrator \& Economic } \\
\text { Development Committee consisting of } \\
\text { elected officials and volunteers }\end{array}$ & $\begin{array}{l}\text { CAO \& Economic } \\
\text { Development Committee } \\
\text { consisting of elected officials } \\
\text { only }\end{array}$ \\
\hline $\begin{array}{l}\text { Small business } \\
\text { development } \\
\text { initiatives }\end{array}$ & $\begin{array}{l}\text { Does some, but mainly taken } \\
\text { care of by Small Business } \\
\text { Enterprise Centre, CFDC, } \\
\text { Chamber of Commerce, Taste } \\
\text { the County }\end{array}$ & $\begin{array}{l}\text { Small Business Enterprise Centre \& CFDC; } \\
\text { collaborate with Hastings County economic } \\
\text { development office on new business and } \\
\text { expansion studies; Township EDO and BIA } \\
\text { collaborate often on special projects }\end{array}$ & $\begin{array}{l}\text { CFDC; Small Business } \\
\text { Enterprise Centre }\end{array}$ \\
\hline $\begin{array}{l}\text { Agriculture \& } \\
\text { natural resource } \\
\text { development } \\
\text { initiatives }\end{array}$ & $\begin{array}{l}\text { EDO and Taste the County take } \\
\text { lead role; actively promoting } \\
\text { small scale and artisan value } \\
\text { added production (e.g. artisan } \\
\text { cheese); promote locally grown } \\
\text { foods; wineries }\end{array}$ & $\begin{array}{l}\text { Agriculture is a priority; work with Harvest } \\
\text { Hastings initiative to promote local food; } \\
\text { opening local food retail store in downtown; } \\
\text { developing monthly fresh harvest meals in } \\
\text { summer; recently hosted Water Buffalo } \\
\text { Food Festival. }\end{array}$ & None \\
\hline
\end{tabular}




\begin{tabular}{|c|c|c|c|}
\hline $\begin{array}{l}\text { Events/arts/culture } \\
\text { initiatives }\end{array}$ & $\begin{array}{l}\text { Both EDO and Taste the County } \\
\text { take lead role }\end{array}$ & $\begin{array}{l}80-90 \% \text { of events led by BIA; EDO acts as } \\
\text { resource }\end{array}$ & $\begin{array}{l}\text { Stratford Shakespeare } \\
\text { Festival; Stratford Tourism } \\
\text { Alliance }\end{array}$ \\
\hline $\begin{array}{l}\text { Downtown } \\
\text { revitalization }\end{array}$ & Picton BIA has lead role & $\begin{array}{l}\text { Township and County EDOs partner; Local } \\
\text { Community Improvement Plan (CIP) } \\
\text { provides financial incentives for façade and } \\
\text { signage and is very successful }\end{array}$ & $\begin{array}{l}\text { Planning Department lead } \\
\text { role; CIP in place providing } \\
\text { incentives; Stratford City } \\
\text { Centre Committee; LACAC }\end{array}$ \\
\hline $\begin{array}{l}\text { Commercial / } \\
\text { industrial business } \\
\text { investment } \\
\text { attraction }\end{array}$ & EDO lead responsibility & $\begin{array}{l}\text { Investment inquiries handled in partnership } \\
\text { with Hastings County; the County just } \\
\text { launched a new Investment Attraction } \\
\text { Strategy }\end{array}$ & $\begin{array}{l}\text { A key focus - mainly } \\
\text { industrial activity - everything } \\
\text { from FAM tours to liaising } \\
\text { with real estate officials; } \\
\text { active partner in South } \\
\text { Western Ontario Marketing } \\
\text { Alliance (SOMA) }\end{array}$ \\
\hline \multirow[t]{2}{*}{$\begin{array}{l}\text { Business retention } \\
\& \text { expansion } \\
\text { initiatives }\end{array}$} & $\begin{array}{l}\text { Not classic BR+E due to limited } \\
\text { time and resources; Primarily } \\
\text { focus on marketing initiatives to } \\
\text { help existing clusters grow (e.g. } \\
\text { wine, cheese) and bring more } \\
\text { business volume, traffic to help } \\
\text { existing business; "Raising the } \\
\text { tide raises all ships" }\end{array}$ & $\begin{array}{l}\text { EDO works closely with BIA to identify } \\
\text { needs; Hastings County completed County- } \\
\text { wide formal BR+E strategy in February, } \\
2009 \text { and actions now being implemented }\end{array}$ & $\begin{array}{l}\text { Do not take proactive role; } \\
\text { noted that a business will } \\
\text { close or leave regardless of } \\
\text { what a local economic } \\
\text { development office can do }\end{array}$ \\
\hline & Prince Edward County & Township of Stirling-Rawdon & City of Stratford \\
\hline $\begin{array}{l}\text { Tourism } \\
\text { marketing } \\
\text { including events, } \\
\text { festivals, } \\
\text { arts/culture }\end{array}$ & $\begin{array}{l}\text { Taste The County is responsible } \\
\text { as DMO; Arts Council has series } \\
\text { of } 4 \text { events; Chamber of } \\
\text { Commerce }\end{array}$ & $\begin{array}{l}\text { EDO and BIA; Hastings County } \\
\text { commencing Premier-ranked Tourist } \\
\text { Project in 2009; County provides } \$ 30,000 \\
\text { to ComfortCountry to coordinate tourism } \\
\text { marketing for the surrounding area }\end{array}$ & $\begin{array}{l}\text { Stratford Tourism Alliance; } \\
\text { Stratford Shakespeare Festival }\end{array}$ \\
\hline
\end{tabular}




\begin{tabular}{|c|c|c|c|}
\hline $\begin{array}{l}\text { Regional } \\
\text { partnerships }\end{array}$ & $\begin{array}{l}\text { Ontario East Economic } \\
\text { Development Commission } \\
\text { (particularly with Creative } \\
\text { Economy Sector); partnering } \\
\text { with } 3 \text { neighbouring counties to } \\
\text { promote artisan cheese } \\
\text { investment (investincheese.ca); } \\
\text { partnering with Durham Region } \\
\text { on Creative Economy research }\end{array}$ & $\begin{array}{l}\text { Hastings County; ComfortCountry; Ontario } \\
\text { East Economic Development Commission }\end{array}$ & SOMA \\
\hline $\begin{array}{l}\text { Relationship with } \\
\text { upper-tier }\end{array}$ & None due to being a single-tier & $\begin{array}{l}\text { County has an Economic Development } \\
\text { Manager and budget that fulfills mentoring } \\
\text { and advice role and is a source of special } \\
\text { project funding; Investment Lead Protocol } \\
\text { signed with County; County itself } \\
\text { proactively involved in county-wide BR+E, } \\
\text { investment attraction, downtown } \\
\text { revitalization, natural resources and } \\
\text { agriculture initiatives; County coordinating } \\
\text { Premier-ranked project }\end{array}$ & None due to being a single-tier \\
\hline $\begin{array}{l}\text { Other initiatives / } \\
\text { comments }\end{array}$ & $\begin{array}{l}\text { When current EDO was hired, } \\
\text { overcame pressures to "woo" } \\
\text { large industrial investment and } \\
\text { instead aligned community assets } \\
\text { with perceived investor demand. } \\
\text { Advice - First get to know your } \\
\text { market, identify strengths and } \\
\text { assets; Then match your strategy } \\
\text { with knowledge of local market; } \\
\text { Third be pro-active in packaging }\end{array}$ & $\begin{array}{l}\text { Township EDO works closely with the } \\
\text { business community; EDO assists BIA } \\
\text { implement their strategies; CIP façade and } \\
\text { signage incentive program has been one of } \\
\text { the biggest successes; Advice - Don't copy } \\
\text { other communities, focus on what is unique } \\
\text { locally and capitalize on your assets }\end{array}$ & $\begin{array}{l}\text { Advice - Working with your } \\
\text { neighbouring communities is } \\
\text { important }\end{array}$ \\
\hline
\end{tabular}




\begin{tabular}{|l|l|l|l|}
\hline & $\begin{array}{l}\text { it all in an easy to understand } \\
\text { fashion and indicate how } \\
\text { investors can participate in your } \\
\text { local economy }\end{array}$ & & \\
\hline
\end{tabular}


Respect local capacity by recognizing existing organizations in the community: Rural communities may already have a Chamber of Commerce, a BIA, a CFDC or a destination marketing (tourism) organization. Any municipality involved, or looking to invest, in local economic development must not ignore, but rather work to complement such existing organizations and fulfill the necessary gaps that cannot be satisfied already. A role for the rural municipality must respect and recognize the needs, desires and successes of existing organizations.

Looking at the rural municipal case studies, both Prince Edward County and the Township of Stirling-Rawdon indicated close working relationships with their local organizations to partner and deliver local economic development. Stirling-Rawdon has created a good bond with their BIA while Prince Edward County has helped accelerate the tourism efforts of their destination marketing organizations like Taste the County.

Partner with neighbouring municipalities and participate in regional consortiums: Regardless of whether a rural municipality has its own full-time EDO or not, the merits of participating in a regional strategy have been made clear. A number of respondents to the survey indicated that they partner with their upper-tier municipality to manage economic development on their behalf. In the case of the Township of Stirling-Rawdon, they split roles and responsibilities with their upper-tier, but partner on occasion when warranted.

It is also found from the exemplary models that they participate in regional consortiums such as the Ontario East Economic Development Commission (OEEDC) ${ }^{3}$ or the Southwestern Ontario Marketing Alliance (SOMA). ${ }^{4}$ Such regional partnerships help with cooperative investment marketing and stretch limited budgets, time and resources by pooling money, staffing and expertise to attract investors that they would not otherwise be able to do individually.

A good example of a regional partnership is the Invest in Cheese initiative mentioned by Prince Edward County. ${ }^{5}$ It is a co-operative program involving Prince Edward, Frontenac, Hastings and Lennox \& Addington Counties. In this case, rather than each rural County battling for cheese investment, they view the region as an attraction and recognize the regional assets. They have even gone so far as to brand themselves collectively as Ontario's Artisan Cheese Region.

\section{Conclusion}

In closing, learning what has worked in other rural municipalities and sharing best practices is certainly important for the design and promotion of rural development. The research reported in this paper furthers the understanding of how rural Ontario municipalities are currently managing

\footnotetext{
${ }^{3}$ http://www.onteast.com

${ }^{4}$ http://www.somasite.com

${ }^{5}$ http://www.investincheese.ca
} 
local economic development. The findings provide help for those municipalities in rural Ontario looking to start, expand or improve their local economic development practice.

No single model was found to offer the best model for all municipalities. Instead, four actions were identified from the interviews with representatives from communities identified as offering examples of "best practice" in rural economic development:

1. Acquire a good understanding of the local community's market and assets and develop an economic development strategy that reflects the local assets.

2. Invest in a full-time economic development officer (EDO), or equivalent.

3. Respect local capacity by recognizing existing organizations in the community that already have a role in local economic development.

4. Partner with neighbouring municipalities and participate in regional consortiums to help conduct investment marketing and other special projects.

These four actions are considered to be an essential starting point for delivering local economic development services in rural Ontario.

\section{Author Biography}

Andrew Redden, a native of Campbellford, Ontario, is the Economic Development Manager for Hastings County in Eastern Ontario. A graduate of Carleton University, Andrew also holds a Master's of Science degree in Planning from the University of Guelph. As well as being a certified economic developer (Ec.D.), he is a Registered Professional Planner (RPP) and full member of the Canadian Institute of Planners.

Prior to his employment at Hastings County, Andrew spent two years coordinating a Province of Ontario main street revitalization pilot project in the small rural communities of Madoc, Marmora, Stirling and Tweed. Among a number of activities in his spare time, Andrew enjoys spending time with family - his wife Meaghan and daughter Lauren.

\section{References}

Agricultural Odyssey Group. (2002). The odyssey report. Prepared for Ontario's Farm Leadership: Christian Farmers' Federation of Ontario, Ontario Agricultural Commodity Council, Ontario Federation of Agriculture \& Supply Management Committee.

Banovetz, James M., Dolan, Drew A., \& Swain, John W. (2000). Overview of local economic development. In Roger L. Kemp (Ed.), Main street renewal: A handbook for citizens and public officials (pp. 16-31). London: McFarland \& Company, Inc., Publishers. 
Blais, Paul., \& Redden, Andrew. (2009). Investing in economic development: Important key indicators municipalities should assess. Municipal World, 19-21.

Bryant, Christopher R., \& Douglas, David J.A. (1995). Ontario: Perspectives on community economic development: Contexts, challenges and the record. In David J.A. Douglas (Ed.), Community economic development in Canada, (Vol 2, pp. 129-168). Toronto: McGraw-Hill Ryerson.

Pulp and paper woes reach far and wide. (2009). Retrieved from http://www.cbc.ca/news/business/pulp-and-paper-woes-reach-far-and-wide-1.830189

Collins-Williams, Maureen. (2008). Serving entrepreneurs in rural areas: MyEntreNet. Rural Research Report, 18 (5), $1-6$.

Internet and broadband availability. (2009). Accessed September 1, 2009 from http://www.crtc.gc.ca/eng/publications/ reports/policymonitoring/ 2009/ cmr53.htm

Cytron, Naomi. (2007). Addressing community and economic development in rural America: Trends, challenges, and opportunities. Community Investments, 3-8.

Douglas, David J.A. (2002). Rural Economic Development in Ontario: Insights gained from recent research. Municipal World, 9-12.

Douglas, David J.A. (2003). Towards more effective rural economic development in Ontario: Findings and recommendations for policies, programmes and practice. Prepared for the School of Environmental Design and Rural Development, Guelph: University of Guelph.

Douglas, David J.A. (2004). Investing in capacity development: An economic development agenda for rural Ontario. Municipal World, 31-37.

Drabenstott, Mark. (2003). Top ten ways to reinvent rural regions. The main street economist: Commentary on the rural economy. Centre for the Study of Rural America, Federal Reserve Bank of Kansas City.

EDAC (Economic Developers Association of Canada). (2007). The essentials of economic development: Practices, principles and planning. Flamborough: Economic Developers Association of Canada

Flora, Cornelia B., Bregendahl, Corry., Fey, Susan., Chen, Lily., \& and Friel, Jennifer. (2004). Rural community and economic development case study review: A summary report. Prepared for 
the Claude Worthington Benedum Foundation, North Central Regional Centre for Rural Development.

Hastings County. (2007). County of Hastings: Economic Development Strategy.

Highman, Paula \& Rathge, Richard. (1998). Population change in the great plains: A history of prolonged decline. Rural Development Perspectives, 13 (1), 19-26.

Howland, Marie. (2003). Applying theory to practice in rural economics. In Richard D. Binham and Robert Mier (Eds.), Theories of local economic development: Perspectives from across the disciplines, (pp. 61-79). Sage Publications.

Industry Canada. (2009). Broadband Canada: Connecting Rural Canadians. Accessed September 1, 2009 from http://www.ic.gc.ca/eic/site/719.nsf/eng/ home

Levman, Bryan. (2004, September 25). Significant numbers leaving GTA. The Toronto Star. pp. N8.

Malatest, R.A. \& Associates Ltd. (2002). Rural youth migration: Exploring the reality behind the myths: A rural youth discussion paper. Canadian Rural Partnership. Government of Canada. Ottawa, Ontario.

Monieson Centre, The. (2008). Rural vitality conference roundtable summary: May 22-23, 2008. London: Queen's University. Accessed from http://easternontarioknowledge.ca/index.php/upcomingevents/past-conferences/85-pastconferences/371-rural-vitality-from-surviving-to-thriving-an-eastern-ontario-perspective.html

Perkins, Martha. (2009). School boards directed to help communities meet needs. The Community Press, 22.

Pezzini, Mario \& Wojan, Timothy R. (2001). Leveraging amenities for rural development: Direction, dialogue, and negotiation. In proceedings: Exploring options for a new rural America. Kansas City: Kansas City Federal Reserve Bank, 121-138.

Premier's Task Force on Rural Economic Renewal. (2001). Report of the Ontario task force on rural economic renewal: Understanding the new rural economy and identifying solutions and opportunities for rural economic development. Prepared for The Honourable Mike Harris, former Premier of Ontario. 
Prince Edward County. (2004). Market Readiness Assessment and Strategic Economic Development Plan. Prepared for Prince Edward County.

Redden, Andrew. (2005). The out-migration of rural young adults: A case study in the municipality of Trent Hills, Ontario. Graduate Thesis. University of Guelph. University School of Rural Planning \& Development.

Richards, Janet. (2009, September 9). Have a local beer: Economic development manager wants industry to grow in Quinte. Belleville Intelligencer, 3.

Robson, Colin. (1993). Real World Research: A Resource for Social Scientists and PractitionerResearchers. Oxford: Blackwell Publishers

Sirolli, Ernesto. (1999). Ripples from the Zambezi. New Society Publishers. Gabriola Island, B.C.

Sirolli, Ernesto. (2009, June 9). Notes taken from Dr. Ernesto Sirolli’s presentation in Ivanhoe, Ontario.

Stirling-Rawdon, Township of. (2005). Stirling-Rawdon Township Community Strategic Plan. Stirling, Ontario

TORC (The Ontario Rural Council). (2002, October 29-30). Proceedings of the $5^{\text {th }}$ annual rural development conference of the Ontario rural council.

Tremblay, Bill. (2008, November 28). Quaker oats plant closure will affect Brighton. The Independent. Accessed on September 1, 2009 from www.northumberlandnews.com. 


\section{Appendix A: Recruitment Letter}

Dear Ontario Municipal Official:

My name is Andrew Redden and I am currently employed by the County of Hastings as Economic Development Manager. As part of a requirement for a course I'm taking through the Economic Developers Association of Canada (EDAC), I must write a major research paper and have chosen to focus on local economic development in rural Ontario.

To help me learn more about how municipalities in rural Ontario choose to get involved in economic development, and what the exemplary models of practice may be, I would like someone from your municipality to help answer a few questions related to this topic. I have put together a short online survey that should take no more than 10 minutes to finish, and there is no right or wrong answer to any of the questions. Please click here to access the survey (or you may access it directly here): http://www.surveymonkey.com/s.aspx?sm=27_2flQOLWWdfvVX. If you have received this email message and are not the best person to complete the survey, please forward my email to the most appropriate person in your municipality.

While research and writings do exist to proclaim the best practices for municipalities to follow, separate research on local economic development in rural communities is needed. By participating in this short survey, you are contributing to a research project that will help determine how economic development is more commonly facilitated in rural municipalities and understand what the best practices are for local economic development in rural Ontario.

All of the surveys and data collected will be kept completely confidential and your name or municipality name is not required. The final results will be tabulated and reported in my final paper. Once my paper is complete and approved later this year, I will send to you a copy by email. Should you have any questions, or have additional information that you feel would benefit this research project, please do not hesitate to contact me by email at andrewredden@ gmail.com or my home telephone number is 613-968-8023.

Sincerely,

Andrew Redden 


\section{Appendix B: Questionnaire}

1. Is your municipality a:

$$
\begin{aligned}
& \text { Single Tier } \\
& \text { Lower Tier } \\
& \text { Upper Tier }
\end{aligned}
$$

2. What is the resident population of your municipality?

3. Does your municipality have an annual operating budget for economic development?

$$
\begin{aligned}
& \square \text { Yes } \\
& \square \text { No }
\end{aligned}
$$

If yes, please state the $\$$ dollar amount for 2009 and outline (if possible) the percentage that covers salaries and/or project funding.

4. Does your municipality have at least one full-time economic development professional on staff?

$$
\begin{aligned}
& \text { Yes (If "Yes" skip to question 6) } \\
& \text { No }
\end{aligned}
$$

5. If you answered "No" to the previous question, and do not have an economic development professional on staff, please describe how economic development at a local level is managed in your local community (then skip to question 9)?

6. Please select the total number of full-time staff and the total number of part-time staff employed to work on economic development in your municipality. From amongst both Full-time and Part-time staff, please also indicate how many have obtained the professional (Ec.D.) certified economic development designation and how many have the Ec.D. Fellowship designation.

7. For municipal economic development staff, what is the reporting relationship (meaning reports to a Clerk, the $\mathrm{CAO}$ etc.)?

8. Briefly describe the core-proactive responsibilities of your municipality for economic development (for example, responsibilities could include tourism, downtown revitalization, natural resources, investment attraction, business retention/expansion, physician recruitment etc.)? 
9. Does your municipality have any formal arrangement or partnerships with other municipalities or organizations to cooperate in delivering economic development services, projects, events or tourism etc.?

$\square$ Yes $\quad \square$ No

If you answered "Yes", please describe

10. Please list a rural community, or rural communities, that you believe are an example of an exemplary model of "best practice" in rural economic development, and briefly explain why in your opinion? 